\title{
A mechanism for automatic preparation of media objects in Ginga-NCL
}

\author{
Marina I. P. Josué \\ MídiaCom Lab - UFF \\ marinaivanov@midiacom.uff.br \\ Joel A. F. dos Santos
CEFET/RJ
jsantos@eic.cefet-rj.br
}

\begin{abstract}
This contribution proposes a mechanism for automatic preparation of media objects incorporated in Ginga-NCL. In the automatic preparation, the middleware Ginga-NCL builds a preparation plan based on the network conditions and the presentation behaviour gathered from the multimedia document that defines the application. The automatic preparation of media objects aims to reduce or avoid synchronization faults during the presentation of distributed multimedia applications.
\end{abstract}

\section{KEYWORDS}

Ginga, media preparation, NCL, multimedia application, preparation plan.

\section{BACKGROUND}

O middleware Ginga-NCL dá suporte à recepção de conteúdo tanto via canal de comunicação broadcast quanto canal broadband. Considerando a transmissão de conteúdo via broadband, alguns atrasos podem ocorrer devido a problemas de congestionamento e redução da vazão de dados. Tal cenário pode levar a falhas de sincronização dos objetos de mídia. A fim de reduzir estas falhas, faz-se necessária a utilização de um mecanismo que prepare antecipadamente os conteúdos dos objetos de mídia. A preparação antecipada pode ser iniciada de forma manual pelo autor da aplicação NCL, na fase de autoria, ou automaticamente pelo formatador, durante a fase de execução da aplicação.

Neste contexto, esta contribuição propõe incorporar a preparação automática de objetos de mídia ao middleware Ginga-NCL, com o objetivo de reduzir ou até mesmo evitar atrasos e, consequentemente, falhas de sincronização durante a exibição de aplicações multimídia. A preparação automática consiste em buscar antecipadamente parte do conteúdo do objeto de mídia, com base na análise da especificação do documento NCL e condições da rede para acesso ao conteúdo dos objetos de mídia.

Para que o Ginga-NCL dê suporte à preparação automática, é necessário criar um plano de preparação baseado nos instantes de apresentação dos objetos de mídia que compõem a aplicação. Durante a fase de análise do documento NCL, o Ginga-NCL constrói um plano de apresentação, que serve como base para prever o tempo

In: Future of Interactive Television Workshop (V WTVDI), Rio de Janeiro, Brasil. Anais Estendidos do Simpósio Brasileiro de Sistemas Multimídia e Web (WebMedia). Porto Alegre: Sociedade Brasileira de Computação, 2019.

ISSN 2596-1683

\author{
Marcelo F. Moreno \\ LApIC - UFJF \\ moreno@ice.ufjf.br
}

\author{
Débora C. Muchaluat-Saade \\ MídiaCom Lab - UFF \\ debora@midiacom.uff.br
}

de preparação, com base nas condições da rede, dos objetos de mídia e construir um plano de preparação automática.

\section{PROPOSAL}

Conforme apresentado na Seção 5.1 da ABNT NBR15600-2, a arquitetura do Ginga-NCL é composta por módulos responsáveis pelo processamento de documentos NCL. Um módulo importante dentro da arquitetura do Ginga-NCL é a máquina de apresentação do conteúdo NCL, também chamada de formatador NCL. O formatador é responsável por controlar as relações de sincronização espaçotemporal entre os objetos de mídia, e pela ativação dos players de mídia.

Para garantir que não ocorram atrasos durante a apresentação dos objetos de mídia transmitidos por uma rede de comunicação, e consequentemente falhas de sincronização, esta proposta propõe a construção de um plano de preparação por parte do formatador, para guiar o carregamento antecipado do conteúdo das mídias.

O evento de preparação é disparado quando um objeto de mídia deve ter seu conteúdo preparado para ser apresentado na aplicação. Um evento de preparação é finalizado quando (i) o buffer do player de mídia estiver completo ou (ii) o conteúdo da mídia a ser preparada for completamente carregado pelo player; sendo considerada a situação que ocorrer primeiro. Para construir o plano de preparação, a máquina de apresentação do Ginga-NCL deve implementar um componente (Parser) que realiza o parsing do documento NCL e constrói uma estrutura para modelar o comportamento temporal da aplicação. A partir desta estrutura, é possível criar um plano de apresentação, que contém os instantes em que cada objeto de mídia deve ser apresentado na aplicação.

A linguagem NCL dá suporte à criação de aplicações multimídia que permitem interação do usuário. A interação do usuário pode disparar a apresentação de um conjunto de mídias, e como não é possível saber a priori se o usuário irá interagir ou não com a aplicação, o formatador deve preparar antecipadamente o conteúdo de todas as mídias relacionadas ao evento de interação.

A interface definida entre o formatador multimídia e cada player de mídia permite que o formatador obtenha informações do player, como o estado de reprodução da mídia (isto é, se a mídia está sendo reproduzida, está pausada ou parada), e o espaço disponível no buffer, por exemplo. Além da comunicação com os players de mídia, o formatador pode se comunicar com outros componentes do ambiente de execução da aplicação, como a interface de rede a fim de obter as condições de transmissão de dados - vazão, jitter e delay, por exemplo. 


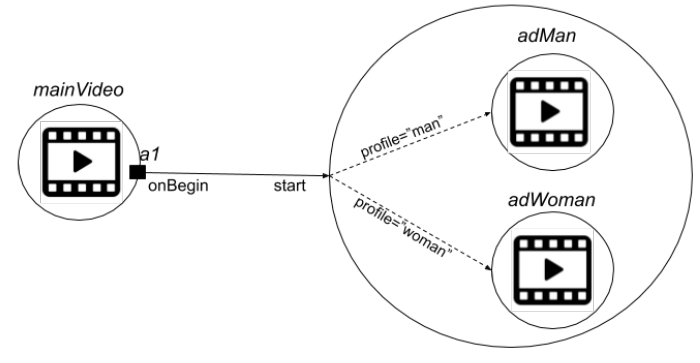

Figura 1: Visão estrutural da aplicação de propaganda direcionada.

Com base no plano de apresentação, que fornece ao formatador o instante de apresentação de um objeto de mídia, o tamanho do buffer do player de mídia (fornecida pela interface com o player) e o tempo para preparar o conteúdo da mídia, o formatador pode calcular os instantes em que cada objeto de mídia deve ser preparado.

Para realizar esta atividade, um elemento chamado Preparation Orchestrator deve ser implementado no formatador. O PreparationOrchestrator calcula a duração de preparação de uma mídia para preparar um certo objeto de mídia através da equação abaixo (Equação 1), onde o parâmetro throughput representa a taxa de transferência de dados na rede, player_inst_time contém o tempo gasto para instanciação do player de mídia e buffer_size, o tamanho do buffer do player de mídia.

$$
\text { dur_preparation }{ }_{\text {media }}=\text { player_inst_time }+\frac{\text { buffer_size }}{\text { throughput }}
$$

O plano de preparação é uma estrutura contendo os instantes de preparação de cada objeto de mídia que compõe a aplicação. Para obter tais instantes, o PreparationOrchestrator utiliza a Equação 2.

$$
t_{\text {preparation }_{i}}=t_{\text {presentation }_{i}}-d u \text { d _preparation }_{\text {media }_{i}}
$$

Quando o formatador implementa a preparação automática de objetos de mídia, uma ação de start no evento de apresentação de um objeto de mídia já preparado tem efeito imediato. Isto reduz as falhas de sincronização durante a apresentação de aplicações multimídia distribuídas.

\section{USE CASE(S)}

A preparação automática de objetos de mídia possibilita a disponibilização de novos tipos de aplicações como a propaganda direcionada. Uma aplicação de propaganda direcionada é composta por um vídeo principal transmitido via broadcast, sincronizado com um segundo vídeo enviado via broadband contendo uma propaganda adaptada ao perfil do usuário. Caso o perfil de usuário definido no receptor seja feminino, uma propaganda de perfume feminino (ad1) será apresentada (barra amarela na Figura 2); e uma propaganda de perfume masculino (ad2) será apresentada (barra laranja na Figura 2), caso contrário. A Figura 1 apresenta a visão estrutural da aplicação.

Para garantir que o conteúdo transmitido via canal broadband será apresentado no momento correto, o formatador deve iniciar

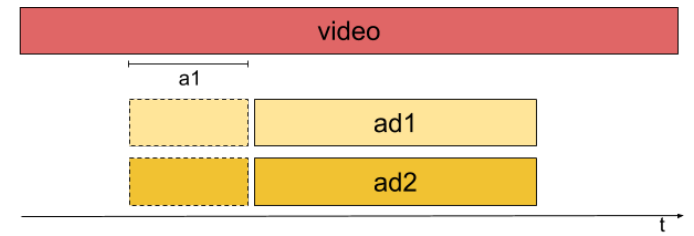

Figura 2: Visão temporal da aplicação de propaganda direcionada.

a preparação do conteúdo alguns segundos antes de sua apresentação. A Figura 2 apresenta a visão temporal da aplicação, na qual a propaganda de perfume feminino (ad1) é representada por uma barra amarela; e a propaganda de perfume masculino (ad2) é representada por uma barra laranja. A ação de preparação automática é representada pelas barras pontilhadas na figura.

\section{AGRADECIMENTOS}

Este trabalho foi parcialmente financiado pela CAPES, CNPq e FAPERJ. 